\title{
Characterization of Partial Coding Region Fibroin Gene on Wild Silkmoth Cricula trifenestrata Helfer (Lepidoptera: Saturniidae)
}

\author{
Suriana $^{a, \#, *}$, D. D. Solihin ${ }^{b, \#, ~ R . ~ R . ~ N o o r ~}{ }^{b, \#, ~ \& ~ A . ~ M . ~ T h o h a r i ~}{ }^{b}$ \\ aPostgraduate of Animal Biology Science, Bogor Agricultural University \\ ${ }^{b}$ Department of Biology, Faculty of Mathematics and Science, Bogor Agricultural University \\ bepartment of Animal Production and Technology, Faculty of Animal Science, Bogor Agricultural University \\ \#Jln. Agatis, Kampus IPB Darmaga, Bogor 16680, Indonesia \\ ${ }^{b}$ Department of Conservation and Ecotourism, Faculty of Forestry, Bogor Agricultural University \\ Kampus Fahutan IPB Darmaga, Bogor 16680, Indonesia \\ (Received 5-12-2010; accepted 25-02-2011)
}

\begin{abstract}
The study was conducted to characterize coding region of wild silkmoth $C$. trifenestrata partial fibroin gene, and detect these gene potential as molecular marker. A total of six larvae $C$. trifenestrata were collected from Bogor, Purwakarta and Bantul Regency. Genomic DNA was extracted from silk gland individual larvae, then amplified by PCR method and sequenced. DNA sequenced result was 986 nucleotide partial fibroin gene of $C$. trifenestrata, which are comprising complete coding region of first exon (42 nucleotide), an intron (113 nucleotide), and partial of second was exon (831 nucleotide). Only coding region was characterized. Results showed that first exon very conserved in C. trifenestrata. These gene consisted of $31 \%$, thymine, $28 \%$ guanine, $21 \%$ cytosine, and $19 \%$ adenine. Cytosine and thymine (sites of $25^{\text {th }}$ and $35^{\text {th }}$ respectively) were marker for C. trifenestrata species. The first exon encoding 14 amino acids. Valine amino acid $\left(12^{\text {th }}\right.$ site) was marker to the species $C$. trifenestrata. The partial second exon consisted of guanine $(32.7 \%)$, alanine $(26.5 \%)$, thymine $(21 \%)$ and cytosine (19.7\%). These region encoded 277 amino acids, which were dominated by the alanine $(27.8 \%)$ and glycine $(\mathbf{2 1 . 6 6 \% )}$. Alanine formed polyalanine sequence with different motifs namely: AAAAAAASS, AAAAAAAAAAAGSSG, AAAAAAAAAAAAGSGTGFGGYDS, AAAAAAAAAAGS SGRGGYDGVDGGYGSGSS, and AAAAAAAAAAAAGSSGRGLGGYDGWVDDGYGSGSGS.
\end{abstract}

Key words: Wild silkmoth, C. trifenestrata, fibroin gene, nucleotide and amino acid marker, polyalanin sequence

\section{INTRODUCTION}

Indonesia is known as a country with mega diversity and mega center of biological resources. Recently many studies have been done on the basis of local genetic resources, for example in local duck (Muzani et al., 2005), sheep (Mansjoer et al., 2007) as well as Bali cattle (Zulkharnaim et al., 2010). Similar studies should be done, especially on Indonesia endemic animals, including pest and beneficial insects.

Silks play important roles in the lives of arthropods, for example, cocoon silks produced by Lepidopteran insects, silk egg stalk by Neuropteran insects, underwater silk prey capture nets by Trichopteran insects, and web building by spiders (Mondal et al., 2007). Silk has been analyzed in some detail in only three Lepidopteran families. In Saturniidae, the silk protein is relatively

*Corresponding author:

e-mail: deasuriana@yahoo.co.id small (200- to 250-kDa). H-fibroin molecules consist of regularly alternating hydrophilic and hydrophobic regions (Hwang et al., 2001) seem to assemble in the elementary secretory units and in the filament polymer as homodimers (Tanaka \& Mizuno, 2001).

The silk consisted of two components, sericin and fibroin. Sericin makes up the protein coating of the silk filament and it secreted into the lumen from cells of the middle division of the silk gland. Fibroin, the main part of the silk, it produced in the posterior region of the silk gland and contains three components: fibroin $\mathrm{H}$ chain, fibroin L chain, and fibrohexamarine/P25 (Zhou et al., 2000). Interestingly, the fibroin L chain and fibrohexamarine $\$ 25$ are not founded in A. yamamai and A. mylitta fibroin (Tanaka \& Mizuno, 2001; Datta et al., 2001b). Most of Saturniidae fibroin protein consists of heavy chain dimer, which are formed by disulfide bound of two cysteine amino acid residues (Sezutsu \& Yukuhiro, 2000; Sezutsu et al., 2010).

However no yet evident for all Saturniidae, expecially Cricula species. Fibroin gene in the various taxa 
vary in size, namely the Bombycoidae family (fibroin gene up to $80009 \mathrm{bp}$ in $B$. mori) while the Saturnidae family (A. pernyi have fibroin gene $9282 \mathrm{bp}$ along Sezutsu \& Yukuhiro, 2000). Although different in size, but there are similarities in the structure of this fibroin gene, which is composed of two exons and one intron (Zhou et al., 2000; Craigh \& Riekel, 2002). Fibroin gene 5 'flanking region (promoter), at bases -300 up to -20 base, in both families are homologous, as well as in first exon in both these families have a high homology. However, intron and the second exon in both families are very different (Zhou et al., 2000).

The difference of fibroin gene is based on the number of nucleotide composition, i.e introns in B. mori consists of $970 \mathrm{bp}$ (Zhou et al., 2000), but intron A. yamamai consists of $150 \mathrm{bp}$ (Hwang et al., 2001), intron A. mylitta consists of $133 \mathrm{bp}$ (Datta et al., 2001b). The second exon in B. mori consists of $15750 \mathrm{bp}$, which encoded 5250 amino acid residues, while the second exon A. yamamai consists of 7923 bp, which encoded 2461 amino acid residues (Hwang et al., 2001) and A. pernyi second exon consists of only $7878 \mathrm{bp}$, which encoded 2626 amino acid residues (Sezutsu \& Yukuhiro, 2000; Zhou et al., 2000). Differences in size and amino acid sequences of these genes may be affected on the physical properties of the fiber (Yonemura \& Sehnal, 2006; Sehnal \& Sutherland, 2008).

To date, all silk and fibroin gene studies of Lepidoptera have focused on B. mory (Bombycidae) (Zhou et al., 2000; Katsuhiko et al., 2007; Lefevre et al., 2007), Antheraea spesies and Samia cynthia ricini (Saturniidae) (Datta et al., 2001a, b; Sezutsu et al., 2009; Sezutsu \& Yukuhiro, 2000; Sezutsu et al., 2010), Araneus diadematus, and Nephila edulis (Araneoidae), Galleria mellonella, and Hepialus californicus (Hepialidae) (Zurovec \& Sehnal, 2002; Yonemura \& Sehnal, 2006; Chen et al., 2006; Saravanan et al., 2006; Collin et al., 2010). No date for $C$. trifenestrata. $C$. trifenestrata is endemic wild silk moth in some islands in Indonesia, while it has silk fiber with the original color of golden yellow, so it is the potential as a natural source of silk fiber. Fibroins are important candidates for the production of transgenic silkworms that would secrete novel types of silk (Komija et al., 2007; Sezutsu et al., 2009; Kobayashi et al., 2009). Furthermore spesivicity of the silk protein has inspired people in both academia and industry to prepare silk-mimetic polymers and proteins by chemical and/or biotechnological means (Hardy \& Scheibel, 2009). It is therefore essential to characterize fibroin genes in species that produce attractive silks as $C$. trifenestarata.

In this study, we describe fibroin gene especially partial coding region of $C$. trifenestrata. We compare the fibroin sequences to those known in other Lepidoptera. We then determine the nucleotide and amino acid composition, and detection nucleotide and amino acid maker for each species. In addition, by comparing the sequences of $C$. trifenestrata to other known fibroins, we shed light on the potential development of these insects as a source of natural silk fibers.

\section{MATERIALS AND METHODS}

\section{Samples}

A total six larvae of the wild silkmoth C. trifenestrata were collected from Bogor and Purwakarta Regency (West Java), and Bantul Regency (Central Java).

\section{Genomic DNA Isolation and Purification}

Genomic DNA was prepared from a pair of silk glands of final instar larvae of C. trifenestrata using a standard technique that has been adjusted (Sambrook et al., 1989; Duryadi, 1993).

\section{Electrophoresis Results of Genomic DNA Purification}

Genomic DNA migrated on $1.2 \%$ agarose gel in 1xTBE solution using the tools Submarine electrophoresis (Hoefer, USA). Ethidium bromide (0.5 ug / ml) used for staining the gel, and then visualized with UV transiluminator $(\lambda=300 \mathrm{~nm})$.

\section{Primer Design}

Primer for DNA amplification of C. trifenestrata fibroin gene was designed by using Primer3 software that available in http://frodo. wi. mit. edu. Primer designed based on Antheraea pernyi fibroin gene (AF083334). This primer consisted of: forward primer FFCt 5'-CATAACCATGAGAGTAATAGCC-3', and reverse primer RFCt 5'-CTGCTGAGTCTGATCCGTAA-3' (Figure 1).

\section{Fibroin Gene Amplification}

Amplification of C. trifenestrata fibroin gene use thermal cycler Eppendorf Type 5332 machine. The PCR amplification was performed using the following procedure: $1 \mathrm{~min}$ at $94^{\circ} \mathrm{C}$, followed by 35 cycles of $30 \mathrm{sec}$ at 94 ${ }^{\circ} \mathrm{C}, 45 \mathrm{sec}$ at $52{ }^{\circ} \mathrm{C}$, and $1 \mathrm{~min}$ at $72{ }^{\circ} \mathrm{C}$, with a subsequent 5 min final extension at $72{ }^{\circ} \mathrm{C}$. Reagent components are: 2 ul DNA template, $1.5 \mathrm{ul}$ of each 10 pmol primer, $12.5 \mathrm{ul}$ of buffer ready to mix, 0.5 ul $\mathrm{MgCl}_{2} 50 \mathrm{mM}$, and added double distilled $\mathrm{H}_{2} \mathrm{O}$ up to 25 ul volume.

\section{DNA sequencing}

DNA sequencing done with DNA sequencing service providers companies.

\section{DNA Alignment and Characterization of C. trifenestrata Fibroin Gene}

The sequence alignment was carried out using ClustalW available at Mega 4.0 software (Tamura et al., 2007). The genes $C$. trifenestrata fibroin were determined by comparing them with homologous regions in $A$. per- 


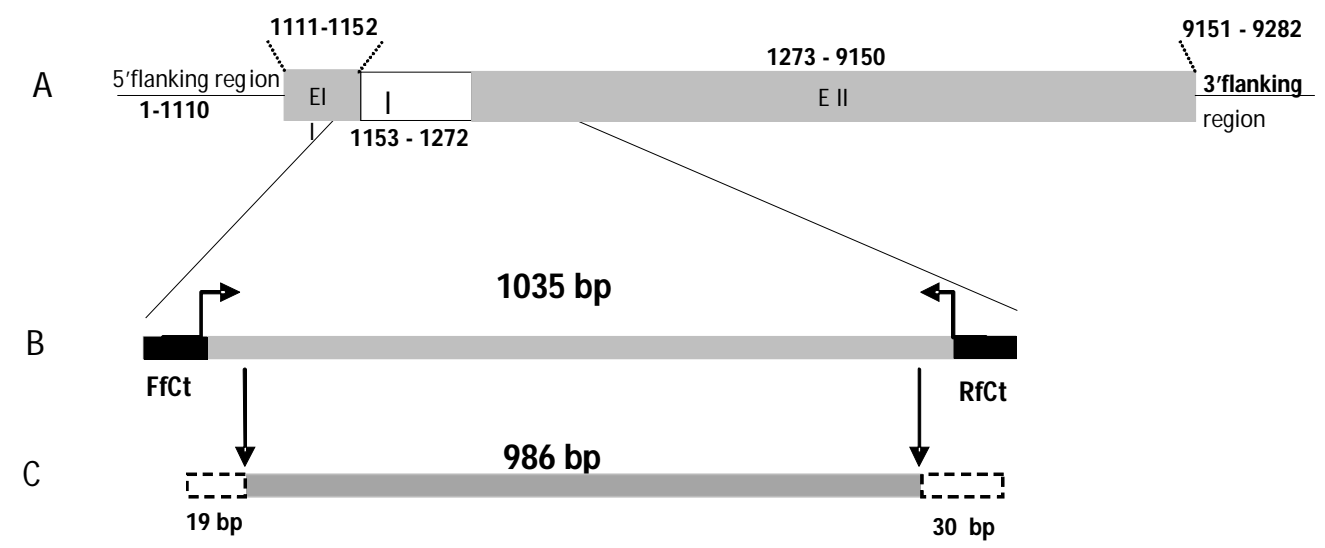

Figure 1. Scheme of the complete sequence fibroin gene A. pernyi (9282 bp). These gene consisting of: 5'flanking region (1110 bp), EI (first exon $42 \mathrm{bp}$ ), intron $120 \mathrm{bp}$, and EII (second exon), $7878 \mathrm{bp}, 132 \mathrm{bp}$ region 3'flanking (AF083334), which was used as templates for designing primers fibroin gene of $C$. trifenestrata (A). The position of primer $\mathrm{RfCt}$ and $\mathrm{FfCt}$ on fibroin gene fragment A. pernyi. The fibroin gene of $C$. trifenestrata was amplified over 1035 bp by these primers (B), and capable to read 986 bp long (C).

nyi fibroin gene. The results of alignment divided into first exon, an intron, and second exon. Only first and second exon that were characterized. These fragments aligned again with known in other Lepidoptera, and then determine the nucleotide type and their composition, amino acid type and their composition, number of different nucleotide and amino acid, and detection diagnostic marker for each species.

\section{RESULTS AND DISCUSSION}

The sequenced results of $C$. trifenestrata fibroin gene from of Bogor, Puwarkarta, and Bantul Regency are the DNA fragments 984-1035 nucleotides (nt) long. After multiple alignment, and cutting no matching sequence, the nucleotide consist of $986 \mathrm{nt}$, which are composed of $42 \mathrm{nt}$ first exon, $113 \mathrm{nt}$ intron and $831 \mathrm{nt}$ partial of second exon. Only coding region (873 nt) was characterized. These sequence have been submitted to GenBank with accession number JF264729, and we will be release after this article was published.

\section{Conserved Nature of First Exon Coding Region Fibroin Gene of $C$. trifenestrata}

The coding region of first exon $C$. trifenestrata fibroin gene (Ct-fibroin) was determined with the initiation codon ATG. This region was highly conserved at spesies level, did not reveal any variation within population of C. trifenestrata (Table 1). Similar results were found in $B$. mori. B. mori fibroin cds consists of 16788 nucleotides. Of these region, the 5 'end ( +1 up to +1449$)$, are identical at $99 \%$ of intra species. One percent variation may result from polymorphism between different strains (Zhou et al., 2000). Besides that, Collin et al. (2010) was aligned H-fibroin of H.californicus and did not reveal any variation intra those population. The fibroin protein is tipycal structural protein, and the main protein in silk fiber, that are spesies spesific (Zurovec \& Sehnal 2002; Mondal et al., 2007). Hwang et al. (2001) have analyzed and aligned 155 nucleotides that includes first exon and the 5 ' end second exon in A. yamamai and also compare them with $A$. pernyi, founded a $95 \%$ similarity in these

Table 1. The first exon nucleotide fibroin gene of C. trifenestrata, Antheraea, and B. mori

\begin{tabular}{|c|c|c|c|c|c|c|c|c|c|c|c|c|c|c|}
\hline \multirow{3}{*}{ Spesies } & \multicolumn{14}{|c|}{ Nucleotide sites } \\
\hline & & & & 111 & 111 & 111 & 122 & 222 & 222 & 223 & 333 & 333 & 333 & 444 \\
\hline & 123 & 456 & 789 & 012 & 345 & 678 & 901 & 234 & 567 & 890 & 123 & 456 & 789 & 012 \\
\hline $\begin{array}{l}\text { C. trifenestrata (B1, B2, } \\
\mathrm{P} 1, \mathrm{P} 2, \mathrm{~J} 1, \mathrm{~J} 2)\end{array}$ & ATG & AGA & GTA & ACA & GCC & TTC & GTC & ATC & CTG & TGC & TGC & GTT & TTG & CAG \\
\hline A. yamamai & $\ldots$ & $\ldots$ & $\ldots$ & $\ldots$ & $\ldots$ & $\ldots$ & $\ldots$ & $\ldots$ & $\mathrm{T}$. & $\ldots$ & $\ldots$ & . C. & $\ldots$ & $\ldots$ \\
\hline A. pernyi & $\ldots$ & $\ldots$ & $\ldots$ & $\mathrm{T}$. & $\ldots$ & $\ldots$ & $\ldots$ & $\ldots$ & $\mathrm{T}$. & $\ldots$ & $\ldots$ & . C. & $\ldots$ & $\ldots$ \\
\hline A. mylitta & $\ldots$ & $\ldots$ & $\ldots$ & $\mathrm{T}$. & $\ldots$ & $\ldots$ & $\ldots$ & $\ldots$ & $\mathrm{T}$. & $\ldots$ & $\ldots$ & . C. & $\ldots$ & $\ldots$ \\
\hline B. mori & $\ldots$ & $\ldots$ & ..C & . A. & . A. & $\mathrm{T} \ldots$ & $\ldots$ & $\ldots$ & $\mathrm{T} \ldots$ & $\ldots$ & $\ldots$ & .C. & C.. & $\ldots$ \\
\hline
\end{tabular}

$\downarrow$ reading direction; (.) identical nucleotide; $\mathrm{A}=$ adenine; $\mathrm{T}=$ thymine; $\mathrm{C}=$ cytosine; $\mathrm{G}=$ guanine; marker nucleotide for $\mathrm{C}$. trifenestrata are written in bold letters. 
sequence. Furthermore, fibroin gene $A$. yamamai has rightly expressed in the posterior silk gland of $B$. mori, indicate that the promoter function and splicing machinery are well conserved between $A$. yamamai, B. mori and other Lepidoptera insect (Zhou et al., 2000; Fangzhou et al., 2002; Kobayashi et al., 2009; Sezutsu et al., 2009). There is homology of fibroin gene in those species, namely base -300 to -20 , including the TATA box (Zhou et al., 2000; Sezutsu \& Yukuhiro, 2000).

Multiple alignment of 42 nucleotidaes first exon fibroin gene $C$. trifenestrata and other genera, showed $83.3 \%(35 / 42)$ nucleotides that are conserved and $16.7 \%$ (7 /42) nucleotides that are vary between them. Variable nucleotides are composed of $7.2 \%(3 / 42)$ parsimony informative and $9.5 \%(4 / 42)$ nucleotides that are singleton. Several nucleotides that are diagnostic, namely: nucleotides $9^{\text {th }}, 13^{\text {th }}, 18^{\text {th }}$, and $35^{\text {th }}$ are diagnostic for $B$. mori (Bombycidae), which are different from the Saturniidae. None the diagnostic nucleotides for the Antheraea genera. However, there are two diagnostic nucleotide for $C$. trifenestrata, which are different from Antheraea and $B$. mori, namely: cytosine ( $25^{\text {th }}$ site) and thymine ( $35^{\text {th }}$ site). These nucleotide are marker for that species (Table 1).

Fourteen amino acid at the fisrt exon $\mathrm{Ct}$-fibroin encoding 14 amino acid residues were also highly conserved at species level. Thirteen of these amino acid, which were identical for $C$. trifenestrata and A. yamamai fibroin heavy chain and 12 with $A$. pernyi and $A$. mylitta. Only 11 amino acid identical to $B$. mori fibroin heavy chain. Note that two cysteine residues were conserved in this region in all four Saturniidae fibroins and B. mori also (Table 2). The high conserved nucleotide (amino acid) of fibroin gene was founded in most Saturniidae (Hwang et al., 2001; Kobayashi et al., 2009; Sezutsu \& Yukuhiro, 2000; Sezutsu et al., 2009; Sezutsu et al., 2010).

From the standpoint of evolution, the amino acid from first exon indicates the existence of specificity between the families. The amino acid threonine $(\mathrm{T})$ was spesific for the Saturniidae family, while the amino acid lysine $(\mathrm{K})$ and $\mathrm{T}$ were spesific in the Bombycidae family. When compared between C. trifenestrata and Antheraea and $B$. mori, there has been reduction in the number of amino acid alanine (A) in $C$. trifenestrata, followed by the addition of the amino acid valine $(\mathrm{V})$. Thus suspected that the divergence begins fibroin gene of $B$. mori to $A$. pernyi and $A$. myliita, then to $A$. yamamai and last was $C$. trifenestrata. Furthermore, the valin amino acid $\left(12^{\text {th }}\right)$ was molecular marker for C. trifenestrata first exon.

\section{Only A Small Range of Sequences Was Conserved in The Partial Second Exon}

The results of multiple alignments 910 nucleotide second exon between $C$. trifenestrata with $A$. pernyi, $A$. mylitta, A. yamamai and B. mori, showed 35\% (314/910) nucleotide were conserved and 62\% (560/910) nucleotide were variable. The number of nucleotides that differ between species and the nucleotide sequence of different positions presented in Table 3. Nucleotide composition of fibroin gene second exon C. trifenestrata consisted of $32.7 \%$ guanine $(\mathrm{G}), 26.5 \%$ adenine $(\mathrm{A}), 21.1 \%$ thymine (T) and $19.7 \%$ cytosine (C). The content of $G$ and A bases were higher than the other bases caused by the use of both these bases as part of a triplet codon for the amino

Table 2. Amino acid the first exon fibroin gene of C. trifenestrata, Antheraea, and B. mori

\begin{tabular}{|c|c|c|c|c|c|c|c|c|c|c|c|c|c|c|}
\hline \multirow{3}{*}{ Species } & \multicolumn{14}{|c|}{ Amino acid sites } \\
\hline & 1 & & & & & & & & & 1 & 1 & 1 & 1 & 1 \\
\hline & $\downarrow_{1}$ & 2 & 3 & 4 & 5 & 6 & 7 & 8 & 9 & 0 & 1 & 2 & 3 & 4 \\
\hline $\begin{array}{l}\text { C. trifenestrata (B1, B2, } \\
\text { P1, P2, J1, J2 ) }\end{array}$ & M & $\mathrm{R}$ & V & $\mathrm{T}$ & A & $\mathrm{F}$ & V & I & $\mathrm{L}$ & $\mathrm{C}$ & C & V & $\mathrm{L}$ & Q \\
\hline A. yamamai & . & . & . & . & . & . & . & . & . & . & . & A & . & . \\
\hline A. pernyi & . & . & . & I & . & . & . & . & . & . & . & A & . & . \\
\hline A. mylitta & . & . & . & I & . & . & . & . & . & . & . & A & . & . \\
\hline B. mori & . & . & . & $\mathrm{K}$ & $\mathrm{T}$ & . & . & . & . & . & . & A & . & . \\
\hline
\end{tabular}

$\downarrow$ reading direction; (.) identical amino acid; $\mathrm{V}=$ valine; $\mathrm{K}=$ lysine; $\mathrm{T}=$ threonine; $\mathrm{A}=$ alanine; $\mathrm{F}=$ phenilalanine; $\mathrm{I}=$ isoleucine; $\mathrm{L}=$ leuicine; $\mathrm{C}=$ cysteine; $\mathrm{Q}=$ glutamine; amino acid marker for $C$. trifenestrata was written in bold letters.

Table 3. Number of different nucleotide second exon partial fibroin gene of C. trifenestrata, Antheraea, and B. mori

\begin{tabular}{lrrrrr}
\hline Species & 1 & 2 & 3 & 4 & 5 \\
\hline 1. C. trifenestrata & - & & & & \\
2. A. yamamai & 233 & - & & & \\
3. A. pernyi & 221 & 81 & - & - & - \\
4. A. mylitta & 232 & 90 & 74 & 381 & \\
5. B. mori & 238 & 391 & 386 & & \\
\hline
\end{tabular}


Table 4. Amino acid sequence second exon partial fibroin gene of C. trifenestrata, Antheraea, and B. mori

\begin{tabular}{|c|c|c|c|c|c|}
\hline Species & & & acid sequence & & \\
\hline & 111 & 1111333344 & 4444444455 & 5555555566 & 66666666777 \\
\hline & 1234567234 & 5678678901 & 2345678901 & 2345678901 & 23456789012 \\
\hline $\begin{array}{l}\text { C. trifenestrata } \\
\text { (B1, B2, P1, P2, J1, } \\
\text { J2) }\end{array}$ & Y A T A K N I GRN & E Y V G N N G E L Y & QRYSTHK QYE & RNAGVSPNLS & GDERLVRTIVV \\
\hline A. yamamai & $\ldots$. . L H HD & $\ldots$ D.H.Q.V & E. F T.R.H. & . . А TR.H. & .N...E. . L \\
\hline A. pernyi & $\ldots \ldots$. $\ldots$ H HD & $\ldots$ D.H.Q.V & E. F T . R.HF. & . . А TR. H. &.$N \ldots$ E... L \\
\hline A. mylitta & $\ldots \ldots \ldots$ н н & $\ldots$ D.HSQ.V & E.FT.R.H. & $\ldots$ ATR.H. & .N...E. . L \\
\hline \multirow[t]{4}{*}{ B. mori } & $A Y . N A \ldots F D E$ & $D \cdot F \cdot A S \cdot A V I$ & EEQI.T.KMQ & . KN KNHG I . G & $K N \cdot K M I K \cdot F \cdot I$ \\
\hline & & & 111111111 & 1111111111 & 11111111111 \\
\hline & 7777777888 & 8888888999 & 9000000000 & 111111111 & 12222222222 \\
\hline & 3456789012 & 3456789012 & 3012345678 & 9012345678 & 90123456789 \\
\hline $\begin{array}{l}\text { C. trifenestrata } \\
\text { (B1, B2, P1, P2, J1, } \\
\mathrm{J} 2 \text { ) }\end{array}$ & E E D P T G H E R I & F E E D D I I K R V & GAAAASS A A A & A A A A S S A A A & I I VERDF G SRR \\
\hline A. yamamai & $\ldots Y \ldots \mathrm{D}$ & $\mathrm{Y} \ldots \mathrm{VV} \cdot \mathrm{N} \ldots$ & PG.SS.A... & $\ldots$ A $\ldots \ldots$ & $\cdots . Q \mathrm{ASHGA}$ \\
\hline A. pernyi & $\ldots$.... D. & Y...VV.N. & PG.SS.A... & $\ldots$ AS .... & $\ldots . Q \mathrm{QASHGA}$ \\
\hline A. mylitta & $\ldots$.... D. & Y...VV.N. & PG.SS.A. . & $\ldots$ AS . . . & . T...QASHGA \\
\hline \multirow[t]{4}{*}{ B. mori } & T T.SD.N.S. & $\mathrm{V} \ldots \mathrm{VLM}$. T L & STV $\cdot Q \cdot Y V \cdot$ & DAGAYSQSGP & Y VSNSGYSTHQ \\
\hline & 1111111111 & 1111111111 & 1111111111 & 1111111111 & 11111111111 \\
\hline & 3333333333 & 4444444444 & 5555555555 & 6666777778 & 88999999999 \\
\hline & 123456789 & 123456789 & 123456789 & 123567890 & 12012345678 \\
\hline $\begin{array}{l}\text { C. trifenestrata } \\
\text { (B1, B2, P1, P2, J1, } \\
\text { J2) }\end{array}$ & G HA A G S A S A A & AS A A A A A A A S & A A G S S G R G L G & G Y D G S V D G G Y & GSGSGSAAAAA \\
\hline A. yamamai &.$G \ldots A \cdot A G$ & . AGSS. RGG. & GFYETHDSYS & S. GS. GA. . A & . G.Y..DS... \\
\hline A. pernyi &.$G \ldots$ A. A G. & . AGSS. RGGG & GFYETHDSYS & $S . G S . G A \ldots V$ & .G.Y.DS... \\
\hline A. mylitta & . G...A.AG. & . A S S S VRGGG & GFYETHDSYS & $S . G S . G A \ldots R$ & . H.Y. . DS. . \\
\hline \multirow[t]{4}{*}{ B. mori } & . Y TSDFSTS. & $\cdot V G \cdot G \cdot G \cdot G A$ & $\ldots$ G A G A G A & $\ldots$ GAASGA. A & . A. A. AG.GYG \\
\hline & 1222222222 & 2222222222 & 2222222222 & 2222222222 & 22222222222 \\
\hline & 9000000000 & 1111111122 & 2222222333 & 3333333444 & 44444456666 \\
\hline & 9012345678 & 1234578901 & 2345789012 & 3456789013 & 45678904567 \\
\hline $\begin{array}{l}\text { C. trifenestrata } \\
\text { (B1, B2, P1, P2, J1, } \\
\mathrm{J} 2)\end{array}$ & AAAAAGS S GR & G G Y D G VDGGY & GSGSS $\underline{A \text { AAA A }}$ & AAAAAAAGSG & TGFGGYDSAAA \\
\hline A. yamamai & $\ldots \ldots$ AAAAG & $S \cdot A G \cdot G \ldots$ & & $\ldots \ldots \mathrm{RRV}$ & GHDRAAG $\ldots$ \\
\hline A. pernyi & $\ldots \ldots$ AAASG & A. GS. GY. . & $\ldots$ D.A... & $\ldots \ldots \ldots$ & G.S...GA... \\
\hline A. mylitta & $\ldots \ldots$ A А АA & S. A G. GH. . & $\ldots$ D.A... & $\ldots \ldots$ AG & A. GR. DGG... \\
\hline \multirow[t]{4}{*}{ B. mori } & T G. G. . A GA G & A. A GAAGA. & . A. AAG.G.G & $Y G . G . G \ldots A A$ & GYGA. AGG. G. \\
\hline & 2222222222 & 2222222222 & 2222222222 & 2333333333 & 333333333 \\
\hline & 6677777777 & 7788888888 & 8999999999 & 9000000000 & 011111111 \\
\hline & 8901234567 & 8901234678 & 9012345678 & 9012345678 & 90124567 \\
\hline $\begin{array}{l}\text { C. trifenestrata } \\
\text { (B1, B2, P1, P2, J1, } \\
\mathrm{J} 2 \text { ) }\end{array}$ & A A A A A A A A A G & S S GRGLGG Y D & G WVD D G Y G S G & $\mathbf{S G S A A A A A A A}$ & $\underline{\text { AAAAGSSG }}$ \\
\hline A. yamamai & $\ldots \ldots$ A & $. G A G . S \ldots G Y$ & $\ldots G . G \ldots D$ &. AA $\ldots \ldots$ & ....SGA \\
\hline A. pernyi & $\ldots \ldots \ldots$ & $\ldots A G . S \ldots G Y$ & $\ldots G \cdot G \ldots . D$ &.$A A \ldots \ldots$ & ...SGA. \\
\hline A. mylitta & $\ldots \ldots A$ & $. G A G . S \ldots G Y$ & $\cdot R G \cdot G \ldots D$ & . АA $\ldots$. & $\ldots$ GSGA \\
\hline B. mori & G. GY G . S GA & $G A . A . Y \ldots V G$ & SGAAS.A. A. & $A . A G S \ldots G S G$ & .G.G.TGA \\
\hline
\end{tabular}

$\downarrow$ reading direction; (.) amino acid identical; amino acid abbreviation refert to Table 2; sequences with different polyalanine motif written in bold and underlined. 
acid alanine has the highest frequency among 3 triplet codons for amino acid alanine, i.e (GCA, GCT, GCG, GCC, with a frequency of consecutive 49,17, 16, 1 times respectively). This result indicated that the composition of the nucleotide was similar, but their size was heterogeneous, such as the second exon of other Lepidoptera (Craigh \& Riekel, 2002; Sezutsu et al., 2010)

\section{Many Repetitif Alanine Amino Acid with Different Motif}

The results of multiple alignments 317 amino acid second exon partial fibroin gen of $C$. trifenestrata and other genera showed that only $63 / 317(20 \%)$ amino acids that were conserved inter genera, and the remaining $223 / 317(70 \%)$ amino acid that were variable. The amino acids that differ between species presented in Table 4 . From Table 4 showed that the amino acid composition has a specific pattern. There is a repetition of the amino acid alanine in sequence starting with the repetition of two up to 12 amino acid alanine (Polyalanin). This Polyalanin followed by amino acids serine and glycine, as well as other amino acids (Table 4). The composition of amino acids after polyalanin a repetition consists of the amino acid glycine $(G)$ and serine $(S)$. The amino acid arrangement like that, was similar with amino acid sequence of second exon fibroin of Saturniidae family (Datta et al., 2001b; Sezutsu et al., 2010 ). There are four type of polyalanine sequence motif in second exon fibroin A. pernyi (Sezutsu \& Yukuhiro, 2000; Sezutsu, et al., 2009), while repetitive GAGASG pattern was founded in B. mori (Zhou et al., 2000). There is a relationship between the composition of nucleotides sequence, amino acids, and the nature of each silk fiber produced by each species, so there is high variability between species. Craigh \& Riekel (2002) explained that these variability due to dynamic evolution of fibroin gene.

As described above, the first exon relatively short than the second exon, while these gene very conserved and the second exon very variable. This case indicates strong functional constraint on them, duplication and subsequent rearrangement of sequences with multiple motifs infers that the rearrangement rate is effectively large relative to the magnitude of negative natural selection. Variation in arrangement of motifs might be selectively neutral or adaptive (Sezutsu \& Yukuhiro, 2000; Sezutsu et al., 2009).

\section{CONCLUSION}

The nucleotide of the first exon fibroin gene of $C$. trifenestrata was 42 nucleotide long, which are conserved in that species. Composition of this nucleotide was dominated by thymine and guanine (over $70 \%$ of total base). Cytosine and thymine (site of $25^{\text {th }}$ and $35^{\text {th }}$ respectively) were nucleotide marker for $C$. trifenestrata species. These exon encoded 14 amino acid residues, which was conservated too. Valine was marker to the species $C$. trifenestrata. Nucleotide composition of partial second exon was dominated by guanine and alanine. These exon encodes 277 amino acids that are dominated by the alanine $(27.8 \%)$ and glycine $(21.66 \%)$. Alanine formed polyalanine sequence with different motifs.

\section{REFERENCES}

Chen, X., Z. Shao, \& F. Vollath. 2006. The spinning processes for spider silk. J. The Royal Soc. of Chem. 2:448-451.

Collin, M. A., K. Mita, F. Sehnal, \& C. Y. Hayashi. 2010. Molecular evolution of lepidopteran silk proteins: Insights from the ghost moth, Hepialus californicus. J. Mol. Evol. 70:519-529.

Craigh, C. L. \& C. Riekel. 2002. Comparative architecture of silks, fibrous proteins and their encoding genes in insects and spiders. Comp. Biochem. and Physiol. 133:493-507.

Datta, A., A. K. Ghosh, \& S. C. Kundu. 2001a. Differential expression of the fibroin gene in developmental stages of silkworm, Antheraea mylitta (Saturniidae) J. Comp. Biochem. Physiol. 29: 197-204.

Datta, A., A. K. Ghosh, \& S. C. Kundu. 2001b. Purification and characterization of fibroin gene from the tropical Saturniid silkworm, Antheraea mylitta. Insect Biochem. Mol. Biol. 31: 1013-1018.

Duryadi, D. 1993. Role possible du comportement dans I'evolution de Deux Souris Mus macedinicus et Mus spicilecus en Europe Centrale. Disertasi. Science et Techiques du Languaedoc. France.

Fangzhou, S., Z. Pingbo, Y. I. Faping, H. Xijun, \& L. Cheng. 2002. Study on fibroin heavy chain of the silkworm Bombyx mori by fluorescence in situ hybridization (FISH). Sci. in China 45:662-668.

Hardy, J. G. \& T. R. Scheibel. 2009. Silk-inspired polymers and proteins. Biochem. Soc. Trans. 37:677-681;

Hwang, J. S., J. S. Lee, T. W. Goo, E. Y. Yun, K. S. Lee, Y. S. Kim, B. R. Jin, S. M. Lee, K. Y. Kim, S. W. Kang, \& D. S. Suh. 2001. Cloning of the fibroin gene from the oak silkworm, Antheraea yamamai and its complete sequence. Biomed. and Life Sci. 4:1324-1326.

Katsuhiko, S., H. Rika, A. Takahiro, T. Masahiro, \& Y. Katsutoshi. 2007. Structure and function of 5'-flanking regions of Bombyx mori fibroin heavy chain gene: Identification of a novel transcription enhancing element with a homeodomain protein-binding motif. Insect Biochem. and Mol. Biol. 37:317-325.

Kobayashi, I., K. Komija, H. Sezutsu, K. Uchino, \& T. Tamura. 2009. Expression of the Japanese oak silkworm Antheraea yamamai fibroin gene in the domesticated silkworm Bombyx mori. Insect Sci. 16:465-473.

Komija, K., Y. Kuwana, H. Sezutsu, I. Kobayashi, K. Uchino, T. Tamura, \& Y. Tamada. 2007. A new method for the modification of fibroin heavy chain protein in the transgenic silkworm. Biosci. Boitechnol. Biochem. 71:2943-2951.

Lefevre, T., M. E. Rousseau, \& M. Pezolet. 2007. Protein secondary structure and orientation in silk as revealed by raman spectromicroscopy. J. Biophys. 92: 2885-2895.

Mansjoer, S. S., T. Kertanugraha, \& C. Sumantri. 2007. Estimasi jarak genetik antar domba Garut tipe tangkas dengan tipe pedaging. Med. Pet. 30: 129-139.

Mondal, M., K. Trivedy \& S. N. Kumar. 2007. The silk proteins, sericin and fibroin in silkworm, Bombyx mori Linn., A review. Caspian J. Env. Sci. 5: 63-76.

Muzani, A., B. Brahmantiyo, C. Sumantri, \& A. Tapyadi. 2005. Pendugaan jarak genetik pada itik Cirebon dan Mojokerto. Med. Pet. 28:109-116.

Sambrook , J., E. F. Fritsch, \& T. Maniatis. 1989. Molecular Cloning Laboratory Manual. $3^{\text {nd }} \mathrm{Ed}$. Cold Spring Harbour Lab. Press, New York. vv EF 
Saravanan, D. 2006. Spider silk structure, properties and spinning. J. of Textile and Apparel, Technol \& Manag. 5:1-20.

Sehnal, F. \& A. Sutherland. 2008. Silk producted by insect labial gland. Proin 2: 145-153.

Sezutsu, H. \& K. Yukuhiro. 2000. Dynamic rearrangement within the Antheraea pernyi silk fibroin gene is asociated with four types of repetitive units J. Mol. Evol. 51:329-338.

Sezutsu, H., K. Uchino, I. Kobayashi, K. Tatematsu, T. Lisuka, N. Yonemura, \& T. Tamura. 2009. Conservation of fibroin gene promoter function between the domesticated silkworm Bombyx mori and the wild silkmoth Antheraea yamamai. J. Insect Biotechnol. \& Sericol. 78:1-10.

Sezutsu, H., T. Tamura, \& K. Yukuhiro. 2010. Leucine-rich fibroin gene of the Japanese wild silkmoth, Rhodinia fugax (Lepidoptera: Saturniidae). Eur. J. Entomol. 105:561-566.

Tamura, K., J. Dudley, M. Nei, \& S. Kumar. 2007. MEGA 4: Molecular Evolutionery Genetics Analysis. Software Version 4. Mol. Biol. Evol. 24:1596-1599.
Tanaka, K. \& S. Mizuno. 2001. Homologues of fibroin L-chain and P25 of Bombyx mori are present in Dendrolimus spectabilis and Papilio xuthus but not detectable in Antheraea yamamai. J. Insect Biochem. Mol. Biol. 31: 665-677.

Yonemura, N. \& F. Sehnal. 2006. The design of silk fiber composition in moths has been conserved for more than 150 million years. J. of. Mol. Evol. 63:42-53.

Zhou C., F. Confalonieri, \& N. Mediana. 2000. Fine organization of Bombyx mori fibroin gene heavy chain gene. Nucl. Acids Res. 28:2413-2419.

Zulkharnaim, Jakaria, \& R. R. Noor. 2010. Identifikasi keragaman genetik gen reseptor hormon pertumbuhan (GHR/Alu) pada sapi Bali. Med. Pet.: 81-87.

Zurovec, M. \& F. Sehnal. 2002. Unique molecular architecture of silk fibroin in the waxmoth, Galleria mellonella . J. Biol. Chem. 277: 22639-22647. 